\title{
EchoGéo
}

$37 \mid 2016$

Femmes et migrations : celles qui restent

\section{Women And Migrations: Those Who Stay}

Introduction

\section{Geneviève Cortes}

\section{(2) OpenEdition}

Journals

Electronic version

URL: https://journals.openedition.org/echogeo/14892

DOI: $10.4000 /$ echogeo.14892

ISSN: 1963-1197

\section{Publisher}

Pôle de recherche pour l'organisation et la diffusion de l'information géographique (CNRS UMR 8586)

\section{Electronic reference}

Geneviève Cortes, "Women And Migrations: Those Who Stay", EchoGéo [Online], 37 | 2016, Online since 07 October 2016, connection on 10 August 2021. URL: http://journals.openedition.org/echogeo/14892 ; DOI: https://doi.org/10.4000/echogeo.14892

This text was automatically generated on 10 August 2021.

EchoGéo est mis à disposition selon les termes de la licence Creative Commons Attribution - Pas d'Utilisation Commerciale - Pas de Modification 4.0 International (CC BY-NC-ND) 


\section{Women And Migrations: Those Who Stay \\ Introduction}

Geneviève Cortes

1 This issue of Échogéo investigates the place of women in international emigration in a range of southern contexts (Central America, Western and Eastern Africa and Southern Asia), with a focus on those who "stay" in the absence of men, and are left behind when the others leave. The role of women in places of emigration has been the object of a number of studies in geography and more broadly in social science from the seventies and eighties, and increasingly so in the nineties. However, in the current context globalised migration, increased diversity of migration flows and migrant profiles, increased complexity of migration processes, facilitation of mobility by new information technologies and tightening of urban-rural link -, a need is arising for new approaches.

\section{Male and female migration}

2 As a preamble, it appears useful to stress that the question of the place of women in our societies, as a social, economic, historic and symbolic construct, goes beyond the sole migratory context. In this respect, English language works on gender studies produced from the 1980s have had a strong influence across the social sciences, embracing diverse geographic contexts in the North and more particularly in the South. For instance, demographer H. Locoh's works (2007) explores the situations of inequality and domination experienced by women in Africa, highlighting their consequences in terms of social and economic development. Likewise, various studies have advocated for the recognition of the women's fundamental role in economic and social development (Boserub, 1983; Charmes, 2005). This increased visibility granted to the role of women, and more generally to the issue of gender relations, has pervaded academic literature for the past thirty years, including works pertaining to the field of migration studies (Lutz, 2010). 
3 The connection between women and migration has slowly emerged as an area of research, and today forms a specific field of study that has been extensively explored by sociology, anthropology and geography, among other disciplines. This emergence appears connected to two facts: on the one hand, the feminisation of migration, that has led to the recognition of women as new protagonists of migratory processes; and on the other hand, the feminisation of points of view on migration (Vause, 2009)1.

\section{The increased visibility of women, focussing on those who leave}

4 A number of studies document past migratory traditions with their respective local characteristics, distinguishing between specific male and female mobility patterns. The traditional model, historically associated with international post-colonial migration flows in the second half of the twentieth century, and more specifically towards Europe and the USA (Simon, 2008), is mostly male. Its pathways were initiated and consolidated by men who joined a number of typically male professional sectors (construction, farm work, mining). Husbands would leave temporarily for a variable length of time, while their wives would stay behind in their place of origin. These traditional male migration channels are diverse and have often endured over time, as illustrated by A. Sayad's work (1977) on the periods of Algerian migration. The figure of the "woman who stays behind" is still prominent in representations of international labour mobility: they are the incarnation of a "geography of stable places", especially in the rural regions of the South (Guétat-Bernard, 2013)².

5 In many regions of emigration, men were then followed abroad by their wives and sometimes their children, following family reunification processes that were in some cases supported by migration policies. These female mobility flows, often referred to as "passive" due to the women's role in decision-making processes and their responsibility for household income, have been studied from the perspective of "family migration". These processes were often associated with the settlement and sedentarisation of migrant communities in their host location. Because women are for the most part absent from the labour market, they have long been ignored or understudied by research on international migration, which accounts for their invisibility in literature (Mirjana Morokvasic, 1984; Krumel, 2012). This invisibility of women, which has been denounced on a broader scale by E. Boserub from the 1970s (Boserub, 1983), can also be explained by the fact that statistical tools did not for a long time measure the flows by gender. It was only from the 1990s that the UN and OECD's global statistics made it possible to compare and characterize the evolution of female migration processes (Zlotnik, 1995; Sauve, 2009).

6 From the 1980s however, new migratory models started to emerge in literature, with a focus on the increasing number of women migrating on their own to work in specific sectors - including both younger single women and married women leaving their husband and children behind. While female migration is reported as a long-standing phenomenon in some regions (Morokvasic, 1984; Gabaccia et al., 2006), these migrant women are referred to as active, autonomous, sometimes a leading force within their household and, according to some authors, active drivers of development (Verschuur and Reysoo, 2005). This led to the emergence of another model, which characterizes many regions and nationalities of emigration: women become "protagonists" of migration (Sauve, 2009), opening up new pathways and integrating within specific 
niches of employment (including the care industry); they then either bring in their men and children, or sometimes continue to manage their families remotely as highlighted by a number of studies on transnational families (Razy and Baby Collin, 2011).

7 According to Castles et al. (1998), the feminisation of migration is one of the five key processes that characterise the "age of migration": a phenomenon associated with the rise of capitalism and of a new international division of labour where the differentiation between social classes, genders and ethnicities plays an important role. According to S. Sassen, globalisation and the rise of inequality particularly affect women, who are forced to emigrate and engage in "survival circuits" (Sassen, 2000).

On a global scale, the feminisation of migration became particularly visible from the 1970-80s, and intensified over the last two decades. This was the result of a growth of feminine migration, including from the South to the North. However, capturing precisely the extent of female migration - and symmetrically, of female non-migration - remains a challenge. First of all, global statistics are for the most part relevant to "stocks" of migrants who are captured in their country of destination, while researchers do not have access to the detail of their origin in their emigration region. Secondly, national census data in countries of origin does not always provide reliable information on international emigration. When this data is available, it rarely includes the socio-demographic profiles of migrant and non-migrant populations, and does not make it possible to differentiate on an infra-national scale (Vause, 2009). It is a fact that it remains difficult to create differentiated statistics along gender lines within one given nationality or region of origin, as this information fluctuates depending on the profiles of individuals and households, on the history of regional migration cycles and on economic climates.

9 Based on 2013 OECD and UN data, the proportion of women within the totality of international migrants was already close to $47 \%$ in 1967 , against $49 \%$ some forty years later. This growth can appear too narrow to justify talking about a feminisation of migration. However, this trend hides very contrasting geographic situations. Female immigration is more prominent in the North than in the South (respectively $53 \%$ vs. just under $45 \%^{3}$ ). Sub-Saharan Africa emerges as the region of the world whose stock of migrants became feminised at the fastest pace over forty years (from $40.6 \%$ women in 1960 to $47.2 \%$ in the 00s), partly due to flows of refugees. In source countries, there has been a regionalisation of female emigration. In some countries - and some regions within these countries - the migrant population is overwhelmingly female: for instance, $80 \%$ of migrants from the Dominican Republic and Cape Verde, and between 60 and $80 \%$ of migrants from Indonesia, the Philippines and Sri Lanka, are women.

10 Overall, the migration of women, including those from Southern countries, as traders, domestic workers, nurses, street vendors, students, etc., has been the object of abundant scholarship across all social science disciplines (Gabaccia et al., 2006; Borgeaud-Garciandia and Georges, 2014; Baby Collin and Péraudin, 2016) .

\section{Women who stay: a gap in scholarship}

11 Considering the global feminisation of migration, it might appear paradoxical - and counter-intuitive - to investigate the women who stay. The question does nevertheless deserve a renewed attention for a number of reasons. 

who stay. While the model of male migration has been the object of ample scholarship in demographics, sociology, anthropology and geography, these works have focused more on the forms of inclusion of migrant men into their place of destination rather than on the impact of their absence on the social and territorial transformation of their place of origin - and even less so, on the place occupied by women in these spaces. Studies focusing more specifically on gender-based approaches to these processes, and documenting the consequences of emigration (including male emigration) on the women who stay behind are scarce and relatively recent.

Starting from a review of existing research on the link between women and migration, Sophie Vause (2009) distinguishes between two main groups of works: those that target migrant women and those that focus on non-migrant women. Out of the former, the author identifies four strands of thought with their corresponding female figures: the first strand analyses reunification, from the perspective of social inclusion, with the figure of the woman as an accompanier. The second looks at the place of women on the labour market (domestic workers, care industry, prostitution, etc.), analysed through the categories of classic economic theory (globalisation, segmentation of the labour market, etc.) or those of transnationalism. The third strand, drawing from the theories of the New Economics of Migration (Stark and Bloom, 1985), places the focus on the role of women in family strategies. Finally, the fourth approach focuses on the importance of migration networks, with a particular focus on women who migrate alone. only mentions a single approach: one that focuses on women as "heads of household" in the absence of men. In other words, "literature on women who are left behind is relatively limited, and even blatantly lacking in the case of international South-North migration" (Vause, 2009, p. 32). Similarly, the international institutions' reports on migration that do address the link between women and migration only deal with migrant women, generally brushing over the issue of women who stay behind (UN, 2006).

This is also explained by the fact that the feminisation of migration is not homogeneous, and cannot be observed across all regions of the world. Within one same region, city, village or rural community, migration behaviours can be highly differentiated. Many women continue to stay behind while their husbands, sometimes taking the children with them, emigrate more or less far away, and for a varying length of time, in search of work and income sources. In fact, in many traditional or emergent spaces, male emigration is still overall predominant, as highlighted since the 1990s by studies from around the world: in Morocco (Sadiqi Ennaji, 2004), Bolivia (Cortes, 2000), India (Aubriot and Bruslé, 2012), Nicaragua (Prunier, 2013), Niger (Boyer and Mounkaïla, 2010), Senegal and the Ivory Coast (Bassett, 2001; Toma, 2014), Egypt (Brink, 1991) and Mexico, which has been studied more extensively (D'aubeterre, 1995; Canabal Cristiani, 2006; Arias, 2009; Garcia Oramas et al., 2011). with professional sectors that are indifferently male or female, sometimes forcing couples and families to split between several destinations to diversify their sources of income. However, even within these regions of emigration, a de facto selection occurs: not all women do emigrate. 
17 Finally, the last reason lies in the need to challenge and deconstruct a number of dualistic categories. For instance, the opposition between "those who stay and those who leave", i.e. migrants and non-migrants, can be simplistic as it is not always the case that these women have never emigrated before, and, even when they have come back, that their everyday life is motionless.

\section{Staying: places and moments}

Engaging in a reflection on "women who stay" in the context of migration requires first of all to clarify a point of a spatiotemporal nature. "Staying" implies the persistence of one's presence in a given place, a village, a city or a country. The challenge lies in qualifying this space: is it the place of emigration? of departure? of origin? of provenance? The place of departure is necessarily defined in relation to a place of arrival - that is, in terms of a spatial trajectory. However, the place of departure is not necessarily the place of "origin" (granted that this term can ever be defined with clarity), and vice-versa. In the contributions to this issue, the terminology varies between authors. In any case, these terms reflect the choice by the researcher of a space of reference (and therefore, of a scale), on which to base the focus range of their study of "staying". Besides, what duration of presence are we talking about? "Staying" implies a duration, which is often assumed to be definitive. On the contrary, migration involves an on-going trajectory in an individual's lifecycle, often punctuated by alternating moments of presence and absence: individuals can accumulate several experiences of mobility. In fact, we now know that the space and chronology of migration challenge traditional segmentations such as origin/destination and temporary/definitive, which fail to accurately capture the reality. The diversity of transnational forms of mobility and migration flows, which has been observed in the last two decades (Faret and Cortes, 2009), comprises of processes such as reversibility (Domenach and Picouet, 2006), the deployment of relational spaces (Béteille, 1981) and complex trajectories including migration, re-emigration, transit, two-way trips, returns or multi-residences, all contributing to blur the researchers' spatial references. The rhythm and shape of these forms of mobility reflect timescales of migration that are connected both to long-term processes in connection with the economic and political climate, and to the life cycles of families and individuals.

In other words, capturing what it means to "stay" involves first of all "immobilising" a migrant/non-migrant (in this instance, the woman) within a personal and familial trajectory, that forms part of a long-term structural territorial change process. The issue is also to do with relocating the "staying places" within a wider space, providing the setting for successive migrations and movements, multi-residences and family dispersal.

\section{Staying: configurations and trajectories}

The authors in this issue address the complexity of the place and chronology associated with staying by analysing a range of socio-territorial configurations and trajectories. Each of those is a variation on a form of presence in the place of origin/departure, or in the place of resettlement. The women who "stay" are first and foremost non-migrants. 
Finally, A. Saïd Chiré and B. Tamru's article explore the migratory area formed by the
horn of Africa (Ethiopia, Somalia and Djibouti) and the Arabic Peninsula. In this region,
Ethiopian immigration is currently changing destinations with the Middle East
becoming a pole of immigration and Djibouti increasingly acting as a place of transit.
The authors question the degree of success and stability of female Ethiopian migrants'

Finally, A. Saïd Chiré and B. Tamru's article explore the migratory area formed by the
horn of Africa (Ethiopia, Somalia and Djibouti) and the Arabic Peninsula. In this region,
Ethiopian immigration is currently changing destinations with the Middle East
becoming a pole of immigration and Djibouti increasingly acting as a place of transit.
The authors question the degree of success and stability of female Ethiopian migrants'

Finally, A. Saïd Chiré and B. Tamru's article explore the migratory area formed by the
horn of Africa (Ethiopia, Somalia and Djibouti) and the Arabic Peninsula. In this region,
Ethiopian immigration is currently changing destinations with the Middle East
becoming a pole of immigration and Djibouti increasingly acting as a place of transit.
The authors question the degree of success and stability of female Ethiopian migrants' of all the other members of their extended families over three generations. She thus highlights complex relations of interdependence between men, women and children, depending on which leave or stay. To achieve this, the author chose to carry out a multi-site survey in several rural communities in the district of Chinandega in the North of Nicaragua, as well as in places of destination in Costa Rica, Spain and the USA.

In the case of non-migrant Mexican women in the South of the State of Oaxaca, Aurélia Michel questions the effects of migration on the evolution of land ownership and family organisation, as well as on the allocation of economic functions. Working from qualitative surveys carried out in villages of origin, the author reconstructs the individual trajectories of several families, revolving around the men's circular migration to the US and to the country's Northern border area.

In the rural mountains of Nepal, where male migration is structured by a long-standing tradition, P. Derioz et al. also investigate the situations of non-migrant women, and more particularly forms of empowerment in a context where patriarchal norms produce a strong discrimination and domination of women, both socially and economically. Using fieldwork carried out on the south side of the Annapurna, close to the city of Pokhara, the authors investigated the part played by women in the development of local tourism and their ability to take initiatives and achieve autonomy through productive innovation.

The women who stay can also be former migrants or returned migrants. Four contributions, referring to the global feminisation of migration, address the issue of staying from the perspective of return migration in urban and rural settings.

Colette Lepetitcorps' contribution, based on bi-site surveys between France and Mauritius, delivers an ethnographic study of female Mauritian emigrants to France, where most of them find employment as domestic workers, who return after spending a long time abroad, most of the time to retire. The author questions the process of returning home and settling to stay. Through fieldwork carried out in Burkina Faso (Ouagadougou, Niangoloko) and the Ivory Coast, Sihé Néya's contribution analyses the diversity of female return processes, both in terms of individual and family strategies.

The article by François Ruf et al. also explores the relation between Burkina Faso and the Ivory Coast but from the chronological perspective of territorial change, in the light of the historical cycles of booms and recessions in the cocoa industry and sociopolitical crises in the Ivory Coast. The authors study the return of Burkinabé women, opening up their analysis to embrace other forms of domestic migration within the Ivory Coast, and delivering a comparative study of various socio-ethnic groups engaged in mobility (Baoulé, Sénoufo, Abron). Drawing from the results of several surveys carried out at various dates in a dozen villages in Ivory Coast cocoa plantation regions, the authors focus on the wives of migrant plantation owners and the reasons and mechanisms of their return to their home country. 
socio-spatial re-inclusion when they permanently return to their country. As well as comparing the situation of migrants from rural and urban areas, the authors use qualitative data collected from migrants staying in the city of Djibouti and others who have returned to Addis-Abeba and other cities located further south (Bishoftou, Hawassa).

\section{Staying... in motion} mobility practices over varying distances, towards nearby cities or rural towns and sometimes across borders. This two-way circulation involves an intermittent presence, sometimes across multiple places of residence, and connects the urban and rural worlds (Vassas, 2015). For example, the re-settlement of female Burkinabé migrants who have returned from the Ivory Coast to live in urban areas involves new mobility patterns (see S. Néya's contribution). The author shows how returned women, in spite of the hardship of living without their husbands in the place where they were sent by them against their will, are far from being passive or just waiting for their husbands to return. Instead, they engage in mobility and circulation practices over varying distances, to develop new activities that complement the insufficient income their husbands wire over to them from the Ivory Coast. To resettle and make the most of their obligation to stay in their country of origin, Burkinabé women paradoxically embrace mobility - a skill they have gained through their previous emigration to the Ivory Coast. After emigrating to follow their husbands through family reunification, they become transnational travelling traders, like many of the women described by several authors in this issue, in Africa and elsewhere (Schmoll, 2005; Potot, 2005).

31

Colette Lepetitcorps' article also analyses the tension between mobility and immobility versus sedentarity. The Mauritius women who find employment as domestic workers settle in France, sometimes for over thirty years. Their inclusion into the country happens within a "compressed" space-time: putting their lives between brackets, almost immobilised, they live in a situation of withdrawal and social isolation due to their demanding conditions of work. According to Colette Lepetitcorps, sedentarity is mostly a dreamed and projected quality, as these women, who exemplify the permanence of the temporary, work in France for long years but never stop expecting to return home. Sedentarity then involves a phase of social re-construction back in Mauritius, a territory they never stopped seeing as their anchor, where their main concern becomes owning their accommodation - sometimes in a rich neighbourhood -, a symbol of both access to a home and of social status. working from the interconnections between various mobility practices within families: 
from the migration of some family members (abroad or within Nicaragua) to the everyday mobility of women in their place of origin due to income-generating activities (agriculture, trade). The author documents the situation of non-migrant women through the prism of interdependence and the constraints it creates.

\section{Social and economic aspects of staying}

33 The second Gordian knot that needs to be untangled is of a social nature. By choosing to focus on the women who stay, the assumption is that these women carry social, economic and spatial traits that differentiate them from migrant men, but also from other migrant women. However, considering the criteria of gender in the analysis of migration does not necessarily mean considering the female population in isolation. The idea is to understand how their position, place, role and status are maintained, transformed, adjusted and renegotiated as part of the relations they form with their social environment (their husband and family, ethnic group, social class) and in their relation to others (Baby Collin and Parraudin, 2016). This brings up the question of women's autonomy and more broadly that of their economic and social empowerment, in the context of broader social issues surrounding relations of power and domination (Taborga, 2007). While these issues are mostly studied with regards to migrant women (Pessar, 2005; Krummel, 2012), the question is also relevant to the women who stay.

Looking at processes of change, there is a controversy as to whether the women who stay are "active" or not, and as to the way they experience the absence of others, participate in it, adapt to it and potentially draw economic and social benefits from their strategies and skills. We refer to Bergeon et al. who note that, in a context where mobility is overrated, our societies tend to "deprecate those who remain still and are assumed to be passive although, in certain contexts, staying requires greater resources and skills than leaving" (Bergeon et al., 2013, p. 3).

\section{Moving beyond dualism}

Literature on women who stay follows two opposing tendencies. According to the first, more critical outlook, women are forced to stay, under the pressure of necessity or tradition. These studies often refer to the figure of "Penelope" whose life is paced by the wait for their man, who is the sole source of income (Boyer, 2013). The picture is one of social and economic dependency, where migration reinforces gender inequality and relations of power, causing tensions and vulnerability (Boyer et Moukaïla, 2010). Many studies by sociologists, anthropologists and geographers have also placed the emphasis on the forms of social control of women that are created and reconstructed in places of origin. In some contexts, this control is exerted by elder men as in Niger (Boyer, 2013) or by the in-laws with whom the wife often stays, in particular when the couple does not yet have a home of its own, as observed in Egypt (Brink, 1991).

According to a more positive outlook, other studies have on the other hand highlighted the active part played by women in the absence of men, in particular as "heads of household" (Bisilliat, 1996; Oso Casas and Catarino, 1996), especially in rural contexts where feminisation is very pronounced (and very visible). The focus is on the empowerment of women and their initiatives in the absence of their husbands. The benefits for women rest in the acquisition of decision-making power, autonomy and 
independence in their spaces of origin. Within a patriarchal system, the international emigration of men is said to open up new spaces for women: spaces of innovation, independence and community action, and even in some cases spaces of political action, since the women find themselves taking on traditionally male responsibilities.

The dualism of interpretative models also appears from a more strictly productive and interpretative point of view. It has been extensively demonstrated that the men's migration can reconfigure the role of wives and mothers, while adding to their domestic tasks. Their roles can be amplified and split between the domestic, educational and productive spheres or between the commercial and non-commercial spheres. In rural areas, studies have analysed amongst other topics the takeover of family farms by women and the feminisation of farm work, with their consequences on local production systems in Western Africa, Latin America or Asia (Basset, 1991; Quiminal, 1991; Cortes, 2000; Gartaula et al., 2010; Aubriot and Bruslé, 2012). Once again, the findings are ambivalent depending on the geographic context. Some studies stress the challenges of sustaining a farm due to the reduction in the family's workforce, while others focus on the positive processes of change and innovation due to the women's involvement in agricultural (or non-agricultural) activities. In more recent studies on subjects including transnational households, the focus was on transfers of money by migrant men, along with their impact on the living conditions of the family members who stayed behind. As the main recipients of these dispatches, and often the main managers of these resources (OIM, 2010), women become increasingly autonomous and apt to take initiatives (receiving money and managing budgets, more equal households, etc.) as observed for instance in Morocco (Sadiqi Ennaji, 2004).

Beyond this dualism, we should consider that mobility can reflect simultaneously processes of empowerment and relations of dependence (Guétat-Bernard, 2013, p. 93), while bearing in mind the ambivalences and the tensions between these two coexisting trends. The very tension between on the one hand passivity and pressure, and on the other hand empowerment and emancipation is precisely where the tenuous cohesion of migrant families is to be found.

\section{A tangle of marital strategies and production mechanisms}

Within the experience of staying or leaving, analysing both individual and collective strategies is probably the best way of capturing the ambivalent social relations at stake around women.

Depending on their marital and family status but also on the social and cultural standards that govern intra-familial social relations and gender relations, migration processes open up new "horizons of autonomy" for women, to quote Colette Lepetitcorps. In the case of Mauritian women, experiences of migration and return are closely connected to the women's marital status. While migration is in some cases a way of breaking free from the constraints of marital life through separation or divorce over the period of migration, or from a relation of domination (domestic violence), returning is a way of escaping from marital and familial pressure.

41 Sihé Néya shows the multiple facets of the women and children's return to Burkina Faso. In the context of insecurity and vulnerability created by the Ivory Coast's crisis in the 2000s, women, who are at the heart of family strategies, were sent back home by their husbands due to marital practices and social norms (marriage of girls, multi- 
residence and dispersion of women associated with polygamy), but also to enable their children to study in Burkina Faso. These patterns are tightly interwoven with the women's more individual aspirations. To meet their need for financial independence and emancipation - made all the more urgent by the situations of vulnerability they face when trying to re-insert themselves in Burkina Faso -, in the absence of their husband, women grasp opportunities to engage in socio-economic activities (paid employment, border trade or cross-border trade, for example between Burkina Faso and the Ivory Coast) and mobility practices.

This entanglement of individual and familial strategies also appears in the article by $F$. Ruf et al. The marital strategies of the Burkinabé, the most polygamous group amongst cocoa farmers, illustrate the choice of leaving or staying in Burkina Faso. Having a cowife, in addition to the one who resides at the cocoa plantation or elsewhere in the Ivory Coast, is also a way of spreading risks and opportunities. The place of staying or return provides a secure place for migrants where they can take shelter in the event of an economic setback, but also a place where they can maintain social bonds, invest in activities, build up their assets or send their children to school. These practices coexist with more specifically female strategies, including the women's involvement in very diverse activities in the place of return (agriculture, catering, small-scale trade, etc.), which enables them to contribute to the household's income. While there is no real emancipation of women on a financial level (money transfers from the husbands remain predominant), these activities provide room for manoeuvre, freeing women from the obligation of working for the cocoa plantation, from which they gain no financial benefits. The same applies to domestic migration: some Abron farmers' wives who stay in their place of origin dedicate themselves to the plantation of cashew trees. These female-led innovation mechanisms, often associated to a reconversion in response to the difficulties encountered by people in cocoa-producing areas, contribute to a new plantation-based economy in the savannah areas of the North of the country.

Looking at the case of rural Mexico, Aurélia Michel documents processes of female empowerment that are also related to production mechanisms, but follow a somewhat different pattern. In a context where women are traditionally excluded from the redistribution of land by the agrarian reform due to land inheritance rules based on virilocality and to the preferential transmission to men, women are increasingly granted access to land. These situations are relevant to the wives of absent men, but also to women who care for the children of other migrant women. These opportunities for accessing property disrupt the gender relations that traditionally preside over the allocation of resources, and act as tokens of appreciation granted to women for the services they perform to migrants.

\section{Differentiating between the degrees of success and freedom margins of the women who stay}

44 The studies conducted by Amina Saïd Chiré and Bezunesh Tamru in Ethiopia aim to articulate return migration with upward social mobility. The authors show how the short-term migration of rural women employed as domestic workers in Djibouti, or that of more educated urban women who emigrate to the Middle East, is aimed at diversifying their family's income but also at climbing the social ladder and achieving financial and personal independence. For these women, the ultimate success is to move 
to the city and buy their own property using savings from their migration. With respect to such ambitions, some women emerge as "losers" (women who return home to their parents"), others as "active" (women who settle into paid employment) and others as "laureates" (women who succeed as micro-entrepreneurs).

From a different angle, Anaïs Trousselle's contribution also documents the diverse situations of women in rural Nicaragua. The author highlights the women's multiple roles, both within their household and within their extended family. Women take charge of household tasks, childcare and farm work and engage in diversified activities (small-scale trad, etc.), as well as being responsible for negotiating the migrants' debts, following up investment projects and safeguarding property assets or access to local resources. The author shows the key part played by women, who continually adjust their own activities and strategies to follow their family members' migrations and projects. Having access to work-related mobility and income-generating activities becomes a major factor in these women's experience of the others' absence, and of their own aspiration to independence. These adjustments can be experienced in a more or less positive manner, which creates a differentiation between the women who stay. The author distinguishes between three types of interdependence: the cases where the migration of other family members (to other domestic cities or abroad) does not stop the women who stay from being active and mobile (locally or across borders); those where migration puts a stop to the women's mobility and activities as they are forced to remain at home; and those where women are only able to become mobile when the migrants are back home.

In the case of Nepal, P. Derioz et al. also show how the emancipation of non-migrant women, associated with touristic development, is characterised by a strong differentiation and varying degrees of success. In this context, the territorial changes generated by the demand for tourism (for instance, through the practice of trekking) are facilitated by public policies, development bodies and the civil society. The authors show how the women who stay benefit from collective support networks and find themselves leading the development of hospitality businesses. While their participation in this industry can be seen as a continuation of their domestic tasks in their role as hostesses (maintenance, cooking, etc.), it also creates a need for innovation, requiring them to gain new skills and experience (such as learning English, for instance) in addition to exploiting their existing skills (such as cooking). However, the benefits of tourism, which are already lesser for women in comparison with the positions available to men in the sector, are not equally accessible to all the women who stay. Setting up a hospitality business requires having access to start-up capital (both financial and human), which is only the case of the wealthiest families belonging to certain ethnic groups (the Gurung to the detriment of the Dalits) and certain castes (Brahmans).

\section{Alterity, projections and identity boundaries}

H. Guétat-Bernard (2013) points out how mobility has disrupted "the construction of male and female identities". This reconstruction of identity does not only occur between males and females, but also between females themselves. Through the experience of Mauritian women, Colette Lepetitcorps investigates precisely the construction of the former migrants' self image, as well as their perception by their family and peers, including other women. Relations of alterity and "identity 
boundaries" between those who stay and those who leave are at the heart of her analysis.

Similarly, in the case of Ethiopian women (A. Saïd Chiré and B. Tamru's contribution), the return of migrant women who were formerly employed as domestic workers depends on whether they resettle in an urban or rural setting. In cities, their inclusion is made difficult by discrimination and prejudice, in particular from men who associate their stay in Djibouti and the Middle East with prostitution. On the contrary, in rural areas, returning migrants are valued because of the resource transfers they facilitate, which can in some cases enable some men to leave.

The issues of identity and of the representation of alterity are also very present in the empowerment of Nepalese women through their participation in the tourism industry. Because they involve developing new skills and taking on new responsibilities, these activities create a dramatic change in the "appraisal of their cultural identity and image" in the local community (P. Derioz et al.).

In these various contributions, although the angles my vary, women's access to financial independence, which is only possible through migration (whether that of others or that of women who have returned), introduces new norms that transgress social boundaries and gender identities in the traditional context of male domination. We should however refrain from adopting an exceedingly unequivocal perspective: as stated by P. Derioz et al., change does not solely and always apply to male vs. female antagonisms, but also to relations of power on other levels (social class, ethnicity, etc.).

\section{Staying, considered within a geography of scattering and connections}

51 The forms and patterns of family organisation produced by international and domestic migration make it necessary to analyse the act of staying within a geography of scattering and connections. It is the persistence of bonds that sheds light on the social, economic and cultural re-composition that takes place around the role and status of women in emigration processes.

\section{Women as hubs of multi-site territories}

52 The geographic scattering of families and their members, according to the model of "confederated households" described by Le Bris et al. (1985), places women at the heart of multi-site systems or territories (Cortes and Pesche, 2013; Baby Collin and Paraudin, 2016). The various contributors to this issue discuss this fact from different angles: François Ruf et al. use the expression "a wife in Burkina Faso, a wife in the Ivory Coast"; Sihé Néya mentions "multi-local integration within a transnational perspective"; Anaïs Trousselle refers to the concept of "multi-local family systems"; and Aurélia Michel describes "archipelago economies".

53 Migrant Burkinabé women (contributions by F. Ruf et al. and S. Néya) provide a perfect illustration of the women's central position within a geography of scattered and multisite territories: their return to their home country responds both to their own individual strategy and to their husband's. Polygamous men scatter their co-wives to consolidate, safeguard and geographically diversify their economic and social 
grounding, creating multiple "family segments" across several sites. For domestic migrants in the Ivory Coast or migrants of Burkinabé origin, returning to their place of origin and staying there enables families to benefit from several economic spaces (F. Ruf et al.).

54 According to Aurélia Michel, the women who stay in the rural areas in the South of the state of Oaxaca in Mexico are the "main drivers" of scattered extended families whose members maintain contact across the distance. The women's function is to maintain the family's local roots, and they contribute to preserving the group's social cohesion by circulating and sharing resources within the extended family. In the absence of other family members, women manage the family assets on behalf of their siblings and provide fundamental support to scattered and vulnerable family members.

This pattern is rather similar to that described by Anaïs Trousselle in the case of Nicaragua's multi-local families. Non-migrant women ensure the continuity of the family's presence in their place of origin and the cohesion of scattered families, sustaining local social and economic assets and sometimes managing productive processes. Women act as receptors, mediators and managers within this networked space, where the circulation of money, goods and information impacts on the family economy and the territorial evolution of the place of departure.

However, the families' and more importantly the women's ability to face and control the implications and social cost of staying behind should not be taken for granted. This issue's contributions all highlight the "fragility" of these social constructions based on scattering. Beyond the group's cohesion, these constructs can reinforce inequalities and forms of exclusion within local Mexican communities (A. Michel), emphasize pressure, loneliness and "the confinement of pain" for Nicaraguan women (A. Trousselle), make it difficult for Nepalese women to adapt to new skills and to inequitable access to autonomy based on social and ethnic belonging (P. Derioz et al.), breed prejudice, rejection and stigmatisation for returning Mauritian women (C. Lepetitcorps), reveal the "shameful facets" of domestic work in the case of Ethiopian women (A. Saïd Chiré and B. Tamru) or fragilize the entrepreneurial activities of returned Burkinabé women (S. Néya).

\section{Blurred categories of analysis and multiple forms of staying}

Finally from a spatial, socio-economic and chronological point of view, and beyond the differentiation of migration patterns along gender lines, what emerges from our contributions is the complexity and mixity of male and female migration trajectories. Beyond their individual strategies and the collective processes they form part of - on the scale of their family, community, village, etc. - women partake in complex and shifting migratory patterns. Within these patterns, multiple individual trajectories are entangled and often articulated, blurring the distinction between males and females, migrants and non-migrants, origin and destination, or mobility and sedentarism. Relations to mobility vary between Northern or Southern countries, rural or urban environments, and depending on the country's economic and socio-historic structures, on the norms that govern social relations and on the functioning of local societies. They reflect the multiplicity of the women's "ways of staying" and, more broadly, the part they play in the transformation of contemporary societies. 
contributions as a whole are a reminder that the migrants' experience of time, which underpins their trajectories, is affected by a set of norms, representations and identification processes. Migration trajectories reveal the power of roots and belonging, of territoriality, and of the identities projected by individuals and families. The affective and symbolic dimension of place, and in particular the country, city or village of origin, affects the women's choices, social relations and everyday or longterm strategies. The main feature highlighted by our various contributors is the very diversity of women's "ways of staying".

\section{BIBLIOGRAPHY}

Arias P., 2009. Del arraigo a la diáspora. Dilemas de la familia rural. México, Universidad de Guadalajara-CUCSH, Miguel Ángel Porrúa, México, 295 p.

Aubriot O., Bruslé T., 2012. Agriculture paysanne népalaise et phénomènes migratoires : de la complémentarité à la rupture des liens ? Revue Autrepart, 3, nº 62, p. 141-158.

Baby Collin V., Perraudin A., 2016. Femmes latino-américaines en contextes de migrations : partir, revenir, rester. Les Cahiers ALHIM, $\mathrm{n}^{\circ} 31$.

Bassett T. J., 1991. Migrations et féminisation de l'agriculture dans le nord de la Côte d'Ivoire. In Gendreau F., Meissalloux C., Schlemmer B., Verlet M., Les spectres de Malthus. Déséquilibres alimentaires, déséquilibres démographiques. Ed. EDI, Orstom, Ceped, p. 219-245.

Bergeon C., Dureau F., Imbert C., Le Roux G., Lessault D., 2013. Et l'immobilité dans la circulation? E-migrinter, $\mathrm{n}^{\circ} 11$, p. 3-6.

Béteille R., 1981. Une nouvelle approche géographique des faits migratoires : champs, relations, espaces relationnels. L'espace géographique, n³, p. 189-197.

Bisilliat J. (ed.), 2003. Regards de femmes sur la globalisation : approches critiques. Paris, Karthala, $314 \mathrm{p}$.

Boyer F, 2013. Interroger l'immobilité : De la figure de Pénélope à celle de migrant pour toute une vie. E-migrinter, $\mathrm{n}^{\circ} 11$ p. 53-64.

Boyer F., Mounkaïla H., 2010. Partir pour aider ceux qui restent ou la dépendance face aux migrations. Hommes \& Migrations, $\mathrm{n}^{\circ}$ 1286-1287, p. 212-220.

Borgeaud-Garciandia N., Georges I., 2014, Travail, femmes et migrations dans les Suds. Revue Tiers Monde, $\mathrm{n}^{\circ}$ 217-1, janvier-mars, $245 \mathrm{p}$.

Brink J. H., 1991. The effect of emigration of husbands on the status of their wives: an Egyptian case. International Journal of Middle East Studies, 23(2), p. 201-211.

Boserup E., 1983. La femme face au développement économique. Paris, PUF, 315 p.

Canabal Cristiani B., 2006. "Y entonces, yo me quedé a cargo de todo...”. La mujer rural hoy. In B. Canabal Cristiani, G. Contreras Pérez et A. León López (dir.), Diversidad rural. Estrategias económicas y procesos culturales. México, UAM-X-Plaza y Valdés Editores, p. 19-37. 
Catarino C., Morokvasic M., 2005. Femmes, genre, migration et mobilités. Revue européenne des migrations internationales, vol. $21, \mathrm{n}^{\circ} 1, \mathrm{p} .7-27$.

Castles S., De Haas H., Miller M. J., 1998. The Age of Migration. London.

Charmes J., 2005. Femmes africaines, activités économiques et travail : de l'invisibilité à la reconnaissance. Revue Tiers Monde, $n^{\circ}$ 182, avril, p. 255-281.

Cortes G., 2000. Partir pour rester : Survie et mutations de sociétés paysannes andines (Bolivie). Paris, Éditions de l'IRD, $413 \mathrm{p}$.

Cortes G., Faret L., 2009. Les circulations transnationales : lire les turbulences migratoires contemporaines. Paris, Armand Colin, 244 p.

Cortes G., Pesche D., 2013. Territoires Multisitués (introduction). Revue l'Espace Géographique, $\mathrm{n}^{\circ} 4$, p. 289-292.

Courgeau D, 1988. Méthodes de mesure de la mobilité spatiale : migrations internes, mobilités temporaires, navettes. Paris, Edition de l'institut national d'études démographiques, $301 \mathrm{p}$.

D’Aubeterre M. E., 1995. Tiempos de espera : emigración masculina, ciclo doméstico y situación de las mujeres en San Miguel Acuexcomac, Puebla. In Soledad González Montes et Vania Salles (dir.), Relaciones de género y transformaciones agrarias. México, El Colegio de México, p. 255-297.

Domenach H., Picouet M., 1987, Le caractère de réversibilité dans l'étude de la migration. Population, vol. 42, $\mathrm{n}^{\circ} 3$, p. 469-483.

Gabaccia D., Donato M. K., Holdaway J., Manalansan IV M., Pessar P. R. (dir.), 2006. Gender and Migration Revisited. International Migration Review, vol. 40, n 1, 256 p.

Gartaula H.N., Niehof A., Visser L., 2010. Feminisation of Agriculture as an Effect of Male Outmigration: Unexpected Outcomes from Jhapa District, Eastern Nepal. The International Journal of Interdisciplinary Social Sciences, vol. 5, $\mathrm{n}^{\circ} 2$, p. 565-577.

Guétat-Bernard H., 2013. Rapports de genre, système de mobilité spatiales et développement rural en Afrique. Geocarrefour, vol. 88, ${ }^{\circ} 2,82 \mathrm{p}$.

Krumel S., 2012. Migrant Women: Stories of Empowerment, Transformation, Exploitation and Resistance. Journal of Ethnic and Migration Studies, vol. 38, $\mathrm{n}^{\circ}$ 7, p. 1175-1184.

Le Bris E., Marie A., Osmont A., Sinou A. 1985. Résidence, stratégies et parenté dans les villes africaines. Les Annales de la recherche urbaine, $n^{\circ} 25$, p. 13-30.

Locoh T., 2007. Genre et sociétés en Afrique : implications pour le développement. INED, $431 \mathrm{p}$.

Lutz H., 2010. Gender in the Migratory Process. Journal of Ethnic and Migration Studies, vol. 36, $\mathrm{n}^{\circ} 10$, p. 16471663.

Morokvasic M. (coord.), 1984. Women in Migration. International Migration Review.

OIM, 2010. État de la migration dans le monde. L'avenir des migrations face aux changements. Genève, 295 p.

ONU, 2006. Vers l'espoir : les femmes et la migration internationale, Fonds des Nations unies pour la Population, État de la population mondiale. New York, FNUAP, 107 p.

Oramas M. J., Ruiz Pimentel S., Ruiz Vallego S., 2011. Las que se quedan: Género, Migración y Control Social. Les Cahiers ALHIM, 21, Migrations et violence(s) en Amérique latine, p. 1-12.

Oso Casas L, Catarino C., 1996. Femmes chefs de ménage et migration. Femmes du Sud, chefs de famille. Edition Karthala, Paris, p. 61-97. 
Pessar, P., 2005. Women, gender, and international migration across and beyond the Americas : inequalities and limited empowerment. Communication présentée à la conférence Expert group meeting on international migration and development in Latin America and the Caribbean, Mexico City.

Potot S., 2005. La place des femmes dans les réseaux migrants roumains. Revue européenne des migrations internationales, vol. $21, \mathrm{n}^{\circ} 1$, p. 243-257.

Prunier D., 2013. De nouvelles ruralités en Amérique centrale ? Dynamiques de mobilités, ressources et organisations familiales. Thèse de doctorat de géographie, Paris-Diderot, $471 \mathrm{p}$.

Quiminal, C., 1991. Gens d'ici, gens d'ailleurs. Migrations soninké et transformations villageoises. Paris, Christian Bourgeois, $222 \mathrm{p}$.

Razy E., Baby Collin V., 2011. La famille transnationale dans tous ses états. Autrepart, $n^{\circ} 57-58$, p. 7-22.

Sadiqi F., Ennaji M., 2004. The impact of male migration from Morocco to Europe on women: a gender approach. Finisterra, WWWIX(77), p. 59-76.

Sassen S., 2000. Women's burden: Counter-geographies of globalization and the feminization of Survival. Journal of International Affairs, 53(2), p. 503-524.

Sayad A., 1997. Les trois "âges" de l'émigration algérienne en France. Actes de la recherche en sciences sociales, vol. 15, juin, Sociologie historique du mandarinat. p. 59-79.

Schmoll C., 2005. Pratiques spatiales transnationales et stratégies de mobilité des commerçantes tunisiennes. Revue européenne des migrations internationales [En ligne], vol. 21, 2005, p. 131-154.

Simon G., 2008. La planète migratoire dans la mondialisation. Paris, Armand Colin, collection U, 255 p.

Stark O., D. Bloom, 1985. The New Economics of Labor Migration. American Economic Review, 75(2), p. $173-178$.

Taborga C., 2007. L'émancipation économique des femmes. Réalités et défis pour l'avenir. Revue internationale des sciences sociales, 2007/1 ( $\left.\mathrm{n}^{\circ} 191\right)$

Toma S., 2014. L'influence mitigée des migrations masculines sur les activités économiques des femmes "qui restent" : étude de cas dans la vallée du fleuve Sénégal. Cahiers québécois de démographie, vol. 43, $\mathrm{n}^{\circ} 2$, p. 345-374.

Vause S., 2009. Genre et migrations internationales Sud-Nord : une synthèse de la littérature. Centre de recherche en démographie et sociétés, Document de travail du Sped, n 32, $50 \mathrm{p}$.

Vassas A., 2015. Partir et cultiver. Essor de la quinoa, mobilités et recompositions rurales en Bolivie. Coll. A travers Champs, Ed. IRD, 308 p.

Verschuur C., Reysoo F. (dir.), 2005. Genre, nouvelle division internationale du travail et migrations. Cahiers Genre et développement, 5, Paris, L'Harmattan, $352 \mathrm{p}$.

Zlotnik H. 1995. The South-to-North Migration of Women. International Migration Review, 29(1), p. 229-254.

\section{NOTES}

1. As highlighted by Vause (2009), literature shows that the term "feminisation" is ambiguous, as it refers to diverse significations and consequently to diverse measuring criteria. 
2. "In addition, this geography of stable places relies upon the naturalisation of the place imposed on women: home, or the place of reproduction. The idealisation of women's stillness (particularly in the case of rural women) is a form of domination" Guétat-Bernard, 2013, p. 92.

3. See Les migrations internationales en chiffres, OECD-United Nations/DAES, October 2013. In Europe has the highest proportion of female migrants (51.9\%), followed by Latin America and the Caribbean (51.6\%), North America (51.2\%), Oceania (50.2\%), Africa (45.9\%) and Asia (41.6\%). In Western Asia (Near East and Middle East), oil-producing countries attract a mostly male immigrant workforce.

4. This literature also points to a feminisation of the point of view on migration: this refers both to analyses conducted by women who study women (female migrants) and to concepts that depict women as the new drivers of migration processes, in particular through their involvement in development.

INDEX

Subjects: Sur le Champ - Sur le Terrain

\section{AUTHOR}

\section{GENEVIÈVE CORTES}

Geneviève Cortes, genevieve.cortes@univ-montp3.fr, is a Professor at Montpellier III University. 